\title{
Portraits of Wives - The Dumbs in the Select Novels of Toni Morrison
}

\author{
Prof. G.Anburaj ${ }^{1 *}$, Dr. T. Mangayarkarasi ${ }^{2}$
}

${ }^{1}$ Assistant Professor of English VIT University, Vellore, Tamilnadu, S. India,

${ }^{2}$ Assistant Professor of English Rani Anna Govt College for Women, Tirunelveli, Tamilnadu, S. India

\author{
DOI: $\underline{10.36348 / \mathrm{sij} 11.2019 . \mathrm{v} 02 \mathrm{i} 10.003}$ \\ | Received: 05.12.2019 | Accepted: 15.12.2019 | Published: 25.12.2019
}

*Corresponding author: Prof. G. Anburaj

\section{Abstract}

This research paper deals a study of the portraits of black women as wives involves an understanding of the role of women as wives in Africa in the pre-colonial times. This is necessary as certain notions about womanhood persist even today in the post-colonial Africa. Black women in the U.S.A. have their roots in Africa as their ancestors were taken mostly from the West Coast of Africa to work as slave's n the plantations of America. Their ideas about the role of men and women were shattered by the system of slavery and very little remained of their traditional roles that affected manwoman relationship. The most important factor with regard to the women in traditional society is their roles as mothers. The importance given to mothers and the high regard in which they were held has been explained in Chapter II. Filomina Chioma Steady points out that "women are important as wives and mothers since their reproductive capacity is crucial to the maintenance of the husband's lineage and it is because of women than men have a patrilineage at all" (Steady, 29). This original research paper portrays the situations of house wives in those novels very clearly.

Keywords: Wives, Novels, Toni Morrison.

Copyright @ 2019: This is an open-access article distributed under the terms of the Creative Commons Attribution license which permits unrestricted use, distribution, and reproduction in any medium for non-commercial use (NonCommercial, or CC-BY-NC) provided the original author and source are credited.

\section{INTRODUCTION}

The role of woman as wife in African societies had a close bearing on her ability to be a mother. Motherhood was the seal of marriage. As a man needed more hands to work in his farm he valued the child bearing capacity of his wife. Traditionally, land was communally owned and distributed according to the ability of the man to farm a certain area. Therefore, polygamy became the traditional form of marriage as it increased the number of wives and the potential of having a number of children to work on the farm. As a result, wives who were barren were scorned and often their bride price was returned and the marriage annulled.

Girl children were not valued as much as boys and there were pressures on women to give birth to boys. As wives, African women had to face the stigma of barrenness, perpetual pregnancy, the pressure on them to produce male children, polygamy and the customs and taboos that go with widowhood. There is another side to the African wife as her economic function as trader is important. As a wife, a woman has to work in the farm and function as a trader to contribute to her husband's household. Therefore, her material needs were not derived from her husband but she had to shoulder the double-burden of the wellbeing of her children and her economic contribution to the household.

The many-sidedness of the African woman's status is astonishing. On the one hand she was idealized as a mother and on the other hand, as a wife she was suppressed by customs that debased her and made her servile. She was able to have an independent income and enjoyed a limited sense of independence but the burden on her was too great as she had to care for her children and contribute towards their upkeep. She contributed to her family through the custom of bride price but the transaction was made between the men of the bride's family and her husband thereby making men as the primary decision-makers in her life. Polygamy differed her some freedom and encouraged the close bonding between mother and child but in the Colonial times, in the urban set up, it worked to her disadvantage. Her function as a trader and her independent earning capacity was undermined during the colonial times. In a changing environment many of the customs and taboos that curtailed her freedom and made her servile continued to oppress her.

In the U.S. to a certain extent, the role of the black wife remained unchanged with regard to her economic function and her close bonding with her 
children. Under the system of slavery Africans were treated as property and denied the rights of human beings. As legal marriage was denied, men were denied the right to fulfil the tradition of the patriarch over the family and women became the backbone of the family. As Joyce A. Ladner points out, "Slave women were forced to assume the basic duties and responsibilities towards their families that men assumed in the white world" (280). The affected the black man-woman relationship, as the black man became a mere subhuman in America with none of the rights and privileges of American men or the African Patriarch. Wives more often "served the vital economic function of providers for their families in the absence of a sustained husbandfather figure" (Ladner 279). This state later led to many black men abandoning their families and leaving the care off the children to their wives. Later, under the sharecropping system black men and women suffered the same hardship as during slavery. Black men became brutal towards their wives. Black women became the repositories of the black man's rage and they were used as "punching bags" as black men found it to be easier to knock them out than the dominant powers. Black women in American had to suffer the twin evils of racism and sexism.

Buchi Emecheta and Mariama Ba address the difficulties of African wives forced into traditional subservient roles through their portraits of wives in their novels. Marshall, Morrison and Walker in their novels examine the problems faced by black wives in a racist society. Women in both Africa and the U.S. suffer due to the inherent sexism in their societies. If black wives in Africa suffer due to oppressive customs that make them firmly second-class, black wives in America are oppressed by their men due to the peculiar historical circumstance in which they find themselves. Their inability to act like men, in a place where they are not able to achieve their manhood, their pentt-up feelings off frustrations make the man crooked and brutal. Whatever be the reason, black wives in Africa and the U.S. face oppression, exploitation and abandonment from their men. The study of the portraits of wives is made fewer than two divisions to explore the female reality of woman as wife in West Africa and the U.S:

- $\quad$ Portraits of Wives by West African writers and

- $\quad$ Portraits of Wives by African-American writers.

If a good wife was in trouble of any kind, instead of calling on god to help her she could call out either the name of her husband or of the god of her husband's people; certainly not the god in the huts of her own father, for they should cease to exist for her, the day her bride price is paid. From that day she should be loyal to her husband, his gods and his people, in body and in spirit.

(Emecheta : The Salve Girl)
... beyond her possessions she (wife) gives up her personally, her dignity, becoming a thing the service of the man who married her, his grandfather, his grandmother, his father, his mother, his sister, his uncle, his aunt, his male and female friends. Her behaviour is conditioned.....

(Mariama Ba : So Long a Letter)

These questions from the novels of Emecheta and $\mathrm{Ba}$ reveal the extent to which black women as wives are debased and expose their second class status in society. In fact, as Molara Ogundipe Leslie asserts in "Not Spinning on the Axis of Maleness" that ".... Married, she [a Nigerian woman] becomes a possession, voiceless and often rightless in her husband's family, except for what accrues to her through her children" (qtd. in Davies, BWWI 68). Emecheta explores this condition of woman in her novels by using the archetypal image of the slave girl and the story of the live burial of the slave girl repeated in two of her novels. She sees the status of wife in African societies as tantamount to that of a salve, where the woman becomes a more possession, a commodity herself neglected and her individuality ignored. Even the glorified image of motherhood is used only to enslave women by prescribing it as their only role in life i.e. to produce children, especially male children. Hence the plight, wives harassed for their barrenness or for giving birth of girls. As a wife, a woman is restricted by customs and taboos which also curtail her freedom during widowhood. $\mathrm{Ba}$ as well as Emecheta mention this period of confinement of widows in their huts or houses which denies them hygiene and autonomy. Ba uses this period of "secluded mourning" as "the archetypal image of female experience," to emphasize " the psychological confinement of a woman in a debilitating stereotypical view of a woman's role" (Stratton, RAL).

In her opening remarks at the special forum on the African women writers at African Women Writers' Conference in London, Lauretta Ngcobo remarked:

It is true that Africa holds two contradictory views of woman-the idealized if not the idolized mother, and the female reality of woman as wife.

(Kunapipi Vol. VII 81-82)

The female reality of woman as wife in Africa is portrayed by both $\mathrm{Ba}$ and Emecheta with telling effect. Emecheta and $\mathrm{Ba}$ protest against the inequities done to woman and their portraits of wives reveal the second class status accorded to them. Emecheta analyses the problems faced by married women in Africa: 1 . The stigma of barrenness 2. Polygamy 3 . The pressures on women to produce male children 4 . Perpetual pregnancy and 5. Widowhood. She exposes the injustices and sufferings inflicted upon women by 
traditional customs and mores. Such customs are actually institutionalized forms of male oppression. The inheritance of widows by their bothers-in-law, the custom that a man may make an unwilling woman his wife by kidnapping her and cutting off a lock of heer hair, the prohibition against women marrying descendents of slaves, and numerous other inhibiting manifestations of traditional culture are all determined and enforced by men. Emecheta and Ba through their portraits of wives show how the African women are oppressed by such customs and how they react to their oppression.

Ogbanje Ojebeta, the slave girl of Emecheta's novel, The Slave Girl, turns out to be a submissive wife, as the understands the oppressive nature of the customs of Ibos, which suppress women. Therefore, she does not question the wisdom in the words of her aunt: "to be owned by a man is a great honour" (SG 158). The idea of a woman as commodity or possession, to be owned by a man does not shock her. Treated as a commodity by her brother and sold into slavery when young, and freed from it with the death of her slave mstress, Ojebeta has come to realize that there is no escape from slavery for a woman, whether she is 'free' or not. She is even pleased with her good fortune, "to select her won master" as she has fortunately escaped the fate of being kidnapped by a stranger and made into his wife. Emecheta tells us that it is pointless to speculate whether Ojebeta and her husband loved each other.

In her own way, Ojebeta was content and did not want more of life; she was happy in her husband, happy to be submissive, even to accept an occasional beating, because that was what she had been brought up to believe a wife should expect (SG 174).

Ojebeta's Christian marriage too limits and confines her in the same way her indigenous culture does: "Slave, obey your master. Wife, honour your husband, who is your father, your head, your heart, your soul" (SG 173). Christianity merely helps to reaffirm sexism. Naturally, Ojebeta can never come out of her slavish mentality trained in the Ibo culture and latterly, Christian dogma. It is not surprising therefore, when she kneels before her husband and confesses: "I could not wish for a better master" (179) when he becomes her formal owner by paying the slave price to her former slave mistress's son. Ojebeta is too defeated, too crowed down to be fully aware of, much less rail against her abasement. The once defiant and clever Ojebeta understands she can never hope to escape the fate of her slavery. The great irony of her story is that even while living as a slave girl in her slave mistress's house, she never acquiesces in her slavery with them, but as a free woman the most she can do, is to select her own master. Through Ojebeta's portrait Emecheta shows how the oppressive customs of Ibo society debase women and points out that the status of a wife is tantamount to that of a slave. Though Ojebeta submissively accepts her basement, the creator of Ojebeta adds an ironic comment.

... as Britain was emerging from war once more victorious, and claiming to have stopped the slavery which she had helped to spread in all her black colonies, Ojebeta, now a woman of thirty-five, was changing masters (SG 179).

Other than the story of Ojebeta, Emecheta presents the story of the live burial of a slave girl along with her dead mistress:

On the eve of the burial she was brought and ordered to lie down in the shallow grave. As might be expected, she resisted, but there was no pity on the faces of the men who stood by watching, amused by her cries... One of the sons of the dead woman lost his patience... and struck the defenceless woman hard at the back of her slaved head... She was still struggling even when the body off her dead mistress was placed on her. She still fought and cried out, so alive. Soon her voice was completely silenced by the damp earth that was piled on both her and the dead woman (SG 62).

The live burial of the futilely defiant slave girl symbolically expresses the plight of all Ibo women restricted by customs. Emecheta uses the symbol of the slave girl to drive home the point of woman's oppression. She repeats this story again in The Joys of Motherhood where the slave girl becomes the 'Chi' of Nnu Ego, the central figure in the novel.

The slave girl thrown into the shallow grave is a recurrent symbol in Emecheta's novels to denote the oppression women suffer. Silenced like the slave woman, by blows either to their bodies or psyches they are forced to submit to the restrictions imposed on them by their patriarchal societies. They are never allowed to climb out of the "shallow grave" of servitude, abasement and loss of freedom. The portrait of Ojebeta and the story of the live burial of the slave girl highlight the condition of woman in the Ibo society as one of victimization and servitude. Ojebeta, in effect, becomes the 'Ogbanje' that she is, "the living dead", when she accepts the shallow definitions of her sex.

Another portraiture of wife is obtained from The Slave Girl, that of Ojebeta's mother. Umeadi. She is an exemplary wife of her culture. She is another victim of patriarchal society. Though her portrait Emecheta draws our attention to the custom that goes with widowhood which undervalues women. With the death of her husband, Umeadi observes a period of mourning during which she is forbidden to visit the stream, bathe, or enter any hut according to the customs of the land. "In fact a woman in mourning was not expected to survive long after the death of her husband ..." (SG 28). Unable to stand the rigours of the mourning period Umeadi dies. On her death, her body 
is thrown into "the bad bush" as required by customs, for she dies during the period of mourning prescribed for widows. This is the respect Umeadi and women like her get for being good traditional wives.

Ma Blackie, in Emecheta's The Bride Price, is yet another wife suppressed by the customs of the land. She is expected to undergo a similar experience like Umeadi on the death of her husband. The custom of inheritance of widows by the brother of the dead husband saves her from the severity of the trail. Okonkwo, her husband's brother, allows Ma Blackie to keep herself clean and wear a neat cotton dress contrary to custom. Through this 'charitable act', he clearly announces his intention of have Ma Blackie as his fourth wife. He prefers to inherit Blackie for his own purposes. He has his eye on Ma Blackie's money and the bride price her daughter would touch as an educated pride.

Through the portrait of Blackie, Memecheta points out how women as wives are exploited and examines the difficulties experienced by them under the system of polygamy. In Okonkwo's household, there are wrangles between wives. Okonkwo's youngest wife, Ezebona, is preferred over other wives and this causes jealousy and quarries. Even Ma Balckie, the inherited wife, is not spared as the other wives feel that Blackie and her daughter are given preferential treatment. Ma Blackie herself is trapped by this marriage to her brother-in-law, as she cannot defend her daughter's choice of her marriage partner. Her joy of having conceived a child is used by Okonkwo to bend her to his wishes. As the wife of Okonkwo, Ma Blackie has to sacrifice her daughter's happiness to please her husband. Her pregnancy is important to her as she remembers the frustrated cry of her first husband who paid a hefty bride price to marry her: "And what had he to show for it all - an only son!” (BP 9). In fact, she was sent to Ibuuza to cure herself of her 'infertility' by her first husband and ironically while she was immersed in the task of recharging her fertility, her husband died. Emecheta draws our attention to the pressures on Blackie to produce a number of male children. Society values wives who are able to give birth to a lot of children, especially male children. Ma Blackie's pregnancy gives her hope that she will have a male child and when she is faced with the task of agreeing with her new husband or supporting her daughter in her choice of a husband, Blackie naturally has to please her husband. She is exploited by her situation as an inherited wife. When her daughter elopes with her lover after a forceful marriage with her kidnapper, Okonkwo gets angry. His plans of using Blackie's daughter's bride price to get a title are thwarted. In great fury, he divorces Blackie by exposing his backside his backside to her in public according to the custom. Ma Blackie has to face this ultimate humiliation. The customs of the society allow him to inherit her as his wifeand even use her daughter's bride price but when things do not work out for him, as he desires, the same custom allows him to insult her. As a wife in the traditional Ibo society, Blackie has to put up with all these humiliations.

Nnu Ego, in The Joys of Motherhood, is also traditional wife who is trapped and enslaved by the customs of the land. Enu Ego has to undergo humiliation for nott giving birth to children and her husband spums her for her barrenness. In a society that sees motherhood as the seal of womanhood Nnu Ego is seen to be worthless because of her barrenness. The second time, however, Nnu Ego satisfies society's expectations of her as a wife. She gives birth to a number of children. But, ironically, Enu Ego finds her condition to be pitiable, as she has to work herself to the bone to bring them up. As a beautiful young wife, she had once felt contempt for her pot-bellied husband, Naife, butt after repeated pregnancies Enu Ego finds herself to be old and haggard. She has to supplement the income by working hard as Naife fails to give her enough foodmoney. Enu Ego feels bitter about the injustice of the situation when the burden of supporting the family falls on her shoulders with Naife away working for the white man's war. "They knew that a traditional wife like herself would never dream of leaving her children" (137). She never abandons her children even when Naife is forcefully taken away to serve in the war and life in Lagos becomes unbearable.

As a wife, Enu Ego not only faces hardship but also humiliation when Naife openly shows happiness about the arrival of the youngest of his inherited wives, Adaku. Naife inherits all his brother's wives on his death and the burden on Nnu Ego's family increases. Poverty and poor living conditions make Enu Ego resent Adaku's arrival. Naife soon becomes "a rare commodity" and to her shame Nnu Ego experiences jealousy, fear and anger. She hates herself for fighting for her husband's favour. The role of the mature senior wife expected of her in their one-room tenement in Lagos unsettles her. The situation is further worsened by Adaku's brazen behaviour. Enu Ego feels that in her village she would have been spared of the humiliation as she would have her own hut butt here there was only "the responsibility and none of the booty" (JM 137).

\section{CONCLUSION}

As a responsible wife Enu Ego is expected to produce only sons but when she gives birth twin-girls, Naife rebukes her. Enu Ego feels sad over her inability to please her husband. Even Adaku, her co-wife, is provoked into telling her that she is somethings more traditional than people at home in Ibuza, and that she worries too much to please her husband. As for Adaku, when she is taunted for having only girls she leaves Naife and vows to educate her girls. She even says defiantly that she will have male companionship. Unlike Adaku, who throws conventions to the winds when she is scorned and ridiculed? Nnu Ego yields and 
submits herself to society's definition of a good wife and customs that enslave women.

\section{REFERENCE}

1. The Handmaid's Tale, Margaret Atwood, Random House UK; 2011
2. Good Wives, Nasty Wenches, and Anxious Patriarchs: Gender, Race, and Power in Colonial Virginia (Published for the Omohundro Institute of Early American History and Culture, Kathleen M. Brown, The University of North Carolina Press; 1996

3. Anna Madgigine Jai Kingsley: African Princess, Florida Slave, Plantation Slaveowner, Daniel L. Schafer, University Press of Florida; 2010

4. Families in Crisis in the Old South Divorce, Slavery, and the Law, Loren Schweninger, the University of North Carolina Press; 2014

5. The Great Gats, F. Scott Fitzgerald, Fingerprint! Publishing; 2014

6. The Diary of a Young Girl, Anne Frank, DIGITAL FIRE; 2010. 